\title{
The Hyperoxic-Hypoxic Paradox
}

\author{
Amir Hadanny ${ }^{1,2,3, *}$ and Shai Efrati ${ }^{1,2,4}$ (D) \\ 1 The Sagol Center for Hyperbaric Medicine and Research, Shamir (Assaf-Harofeh) Medical Center, \\ Zerifin 70300, Israel; efratishai@outlook.com \\ 2 Sackler School of Medicine, Tel-Aviv University, Tel-Aviv 6997801, Israel \\ 3 The Mina and Everard Goodman Faculty of Life Sciences, Bar Ilan University, Ramat-Gan 5290002, Israel \\ 4 The Sagol School of Neuroscience, Tel-Aviv University, Tel-Aviv 6997801, Israel \\ * Correspondence: amir.had@gmail.com; Tel.: +972-544707381; Fax: +972-8-9779748
}

Received: 27 May 2020; Accepted: 22 June 2020; Published: 25 June 2020

\begin{abstract}
Effective metabolism is highly dependent on a narrow therapeutic range of oxygen. Accordingly, low levels of oxygen, or hypoxia, are one of the most powerful inducers of gene expression, metabolic changes, and regenerative processes, including angiogenesis and stimulation of stem cell proliferation, migration, and differentiation. The sensing of decreased oxygen levels (hypoxia) or increased oxygen levels (hyperoxia), occurs through specialized chemoreceptor cells and metabolic changes at the cellular level, which regulate the response. Interestingly, fluctuations in the free oxygen concentration rather than the absolute level of oxygen can be interpreted at the cellular level as a lack of oxygen. Thus, repeated intermittent hyperoxia can induce many of the mediators and cellular mechanisms that are usually induced during hypoxia. This is called the hyperoxic-hypoxic paradox (HHP). This article reviews oxygen physiology, the main cellular processes triggered by hypoxia, and the cascade of events triggered by the HHP.
\end{abstract}

Keywords: hyperoxia; hypoxia; hyperbaric oxygen; biogenesis; hyperoxic-hypoxic paradox; hypoxia-inducible factor (HIF)

\section{Introduction}

Oxygen is the third-most abundant element in the universe, after hydrogen and helium, and it is the most dominant effector of most living creatures on earth. About 300 million years ago, during the Carboniferous period, atmospheric oxygen levels reached a maximum of 35\%, which may have contributed to the large size of animals and insects at this time [1,2]. Today, oxygen constitutes $20.8 \%$ of the earth's atmosphere, and any slight change in its concertation will have a dramatic impact on all levels of mammalian physiology. The ability to maintain oxygen homeostasis is essential for survival, and all mammalian physiological systems evolved to ensure the optimal level of oxygen supplied to all cells in each organism. This has transpired through the evolution of a complex physiological infrastructure for oxygen delivery (the lungs), oxygen transport carriers (erythrocytes and plasma), oxygen transport pathways (vascular system), and the pump (heart). Both the development and regulation of these systems in organisms provide the basis for oxygen homeostasis.

Effective metabolism is highly dependent on a narrow therapeutic range of oxygen. Accordingly, low levels of oxygen, or hypoxia, are one of the most powerful inducers of gene expression, metabolic changes, and regenerative processes, including angiogenesis and stimulation of stem-cell proliferation, migration, and differentiation. The sensing of decreased oxygen (hypoxia) levels or increased (hyperoxia) oxygen levels occurs through specialized chemoreceptor cells and metabolic changes at the cellular level which regulate the response. Interestingly, in the cellular milieu, fluctuations in free oxygen concentrations rather than the absolute level of oxygen can be interpreted as a lack of oxygen. Thus, intermittent increases in oxygen concentration can induce many of the mediators and cellular 
mechanisms that are usually induced during hypoxia. This is the so- called hyperoxic-hypoxic paradox (HHP).

In this article, we review oxygen physiology, the main cellular processes triggered by hypoxia, and the cascade of events triggered by the HHP.

\section{Oxygen Homeostasis}

All of our body's tissues rely on a continuous oxygen supply at a rate that matches the changing metabolic demands. The oxygen delivery chain begins at the lungs, with the destination being the mitochondria (Figure 1). Oxygen is delivered by convection in the airways and blood vessels. It then diffuses across the alveolar-capillary membrane and through the capillary wall to the interstitium and to its destination, the mitochondria. In the blood, oxygen is carried in two forms-a fraction that is bound to hemoglobin and a free fraction dissolved in the plasma. The amount of dissolved oxygen is proportional to the oxygen partial pressure at a specific temperature, according to Henry's law [3]. At physiologic normoxic conditions, i.e., at normal content of inspired oxygen (20.8\%), most (up to $99 \%$ ) of the oxygen is carried by hemoglobin, and the dissolved quantity of oxygen is small [4]. Therefore, the amount of red blood cells will dominantly affect the total capacity of oxygen delivery. However, at an elevated partial pressure of oxygen (such as breathing pure oxygen and during a hyperbaric exposure), the dissolved amount can become significant. In all cases, the diffusion gradients are oxygen's driving force from the plasma to the mitochondria. Thus, the free dissolved fraction has a dominant effect on the mitochondria. It is assumed that oxygen freely diffuses across cell membranes. However, recent data indicate that water channels, such as aquaporin-1 (AQP-1), also work as oxygen transporters [5].

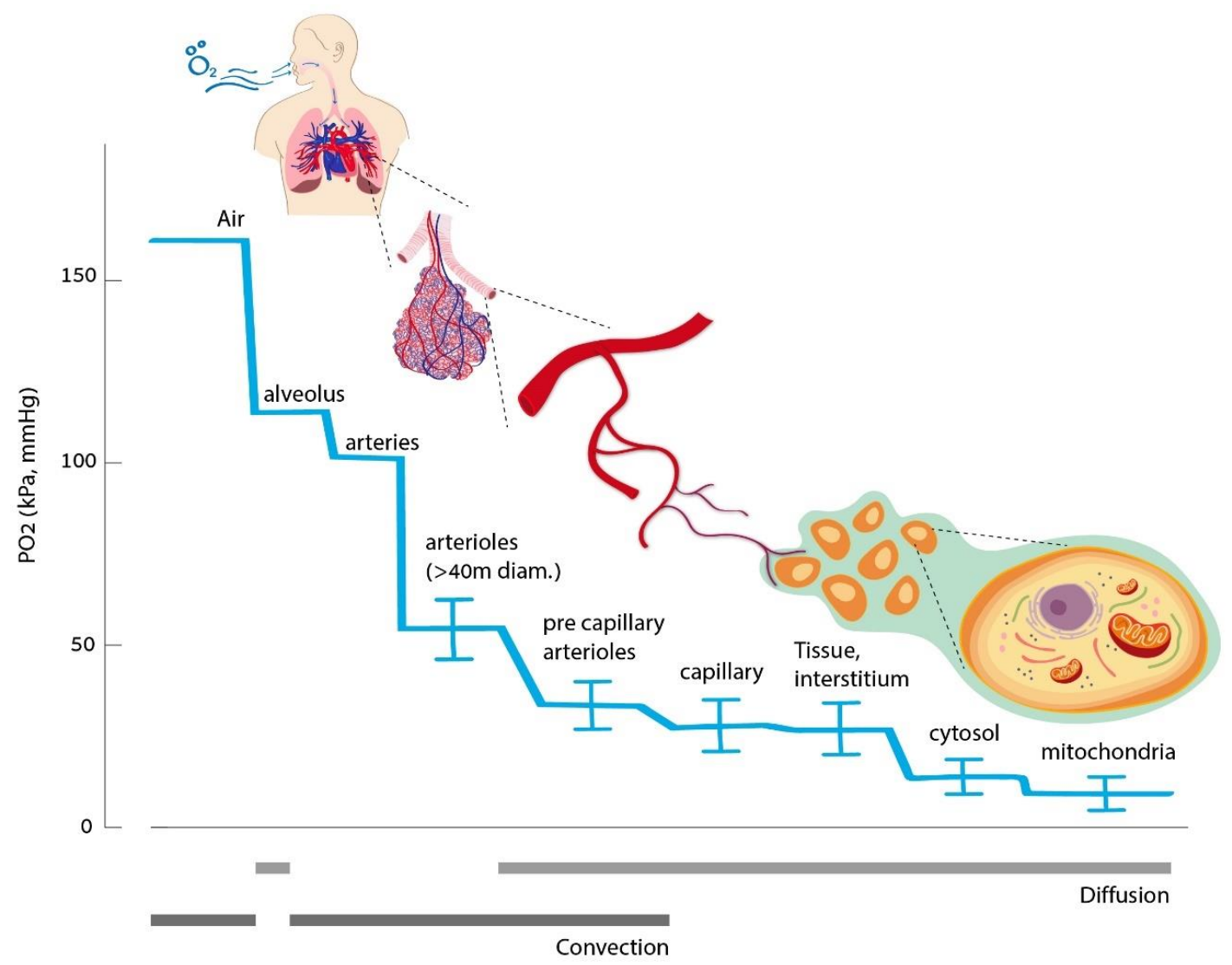

Figure 1. Oxygen delivery chain.

At the normal steady state, oxygen homeostasis is a dynamically regulated process. The physiological cellular demand for oxygen can vary depending on tissue requirements at a 
given moment. For example, an exercising muscle has significantly higher oxygen demand than a relaxed muscle. Consequently, the oxygen delivery rate to tissues is continuously adjusted.

Several mechanisms enable the human body to maintain an adequate oxygen supply [6]. The systemic sensing and response to hypoxia include (a) carotid body glomus, a chemosensor in the arterial circulation that can increase the ventilation rate, (b) and the neuroepithelial bodies (NEBs), which are clusters of cells exposed to the airway lumen at branching points, innervated by the Vagus nerve which dilate the pulmonary arteries to optimize the ventilation-perfusion exchange. The adrenergic system is activated during hypoxia, increasing cardiac output and selective blood perfusion to the more crucial organs. At the organ level, arteries dilate in response to hypoxia to increase oxygen delivery. Oxygenation levels are also sensed by the kidneys, which regulate erythropoietin production to adjust the number of red blood cells (RBC) and oxygen-carrying capacity. In addition to the dynamic respiratory and metabolic systems allowing increased oxygen delivery, as outlined above, it is necessary to have regulating mechanisms at the cellular level. These are essential for survival at extreme environmental conditions and pathological/disease states where systemic regulation is insufficient.

At the cellular level, $80 \%$ of the available oxygen is used by the mitochondria, while only $20 \%$ is used by other organelles. Being the major oxygen consumer and metabolizer, the partial pressure in the mitochondria is very low, only 1-3 mmHg (Figure 1). Mitochondria are, therefore, the key oxygen sensor, as well as important signaling organelles [7]. Most evidence so far points to the following theory: mitochondria signal the onset of hypoxia by generating reactive oxygen species (ROS) signals by the electron transport chain. When ROS are released to the intermembrane space, they interplay with the activation of enzymes, transcription factors, and post-translation responses [8].

In addition, several cells can adapt to reduced oxygen levels by unique mechanisms [6]. For example, the hemoglobin in red blood cells can change its form and affinity under hypoxic conditions [4]. Cytochrome P-450 monooxygenases (CYP) include a vast number of homologous oxygen-sensitive proteins that oxidize a wide range of compounds. Numerous reports have suggested that CYP metabolites contribute to the hypoxia response in the systemic microvasculature and endothelium, and may contribute to hypoxic pulmonary vasoconstriction $[6,9,10]$.

\section{Hypoxia-Induced Cellular Cascade}

As detailed above, effective metabolism is highly dependent on a narrow therapeutic window of oxygen. However, while the arterial oxygen partial pressure in adult mammals is $\approx 100 \mathrm{mmHg}$, in the mammalian fetus, it is around $40 \mathrm{mmHg}$. Thus, hypoxia is a relative term and is most usefully defined as a condition in which failure of either delivery or utilization of oxygen limits normal function.

\subsection{Hypoxic Inducible Factor}

A low level of oxygen is signaled by all living cells, which starts with a class of enzymes called prolyl hydroxylase domain (PHD) proteins [11,12] (Figure 2). Under normal oxygen concentrations, these PHD enzymes include oxygen-sensing hydroxylases which hydroxylate specific proline and asparagine residues on the $\alpha$-subunit of the transcription factor hypoxia-inducible factor (HIF). Following hydroxylation, the HIF- $1 \alpha$ subunit is targeted by the E3 ubiquitin ligase, also known as the von Hippel-Lindau protein (VHLp), which induces HIF-1 $\alpha$ ubiquitination and degradation. Factor inhibiting HIF (FIH) is an additional hydroxylase, which hydroxylates an asparagine residue on the $\alpha$-subunit of HIF, deactivating the HIF transcription factor. HIF is a heterodimer composed of HIF- $1 \alpha$, HIF- $2 \alpha$, or HIF- $3 \alpha$ subunits, which dimerize with HIF- $1 \beta$, HIF- $2 \beta$, and HIF- $3 \beta$ subunits respectfully forming HIF-1, HIF-2, and HIF-3 factors. HIF- $1 \alpha$ is produced in all cell types while the HIF- $2 \alpha$ subunit is found in specific cells, including myeloid cells, liver parenchyma, vascular endothelia, type II pneumocytes, and renal interstitium. While HIF-1 and HIF-2 function as lead regulators of the transcriptional response to hypoxia, the HIF-3 function is yet to be known. Although the HIF1A gene 
is constitutively expressed at low levels under normoxic conditions, it is significantly upregulated in response to hypoxia [13].

HIF-1, when stabilized by hypoxic conditions (without hydroxylases repression) (Figure 2), serves as a transcription factor that regulates over 100 genes essential for survival in oxygen-deprived conditions [14]. These include glycolysis enzymes, which allow adenosine triphosphate (ATP) synthesis in an oxygen-independent manner, enzymes decreasing the basal respiratory rate, and upregulating the vascular endothelial growth factor (VEGF) to induce angiogenesis which improves tissue perfusion. Unlike HIF-1, HIF-2 regulates iNOS (inducible NO synthase) and other factors that support increases in tissue oxygenation in adults, such as erythropoietin production [15]. In addition to modulating cellular metabolism needs for survival in a hypoxic environment, HIF-1 can either turn on or off key mammalian regeneration processes [16-18]. In controlled mammalian models, it was demonstrated that continuous downregulation of HIF-1 results in a scarring response and loss of tissue [16]. HIF-1 also has an important role in the regeneration and maintenance of essential organ functions that are highly oxygen-dependent such as the brain and the heart. Research conducted on mice demonstrated that increased HIF expression is neuroprotective and enhances regenerative effects that can enhance hippocampal memory and induce better neuroregeneration in post-stroke and spinal cord injuries $[17,19,20]$. With regard to the heart, increased HIF expression initiates the metabolic processes needed to regenerate the damaged myocardium and improve cardiac functions after various types of injuries $[18,21]$.

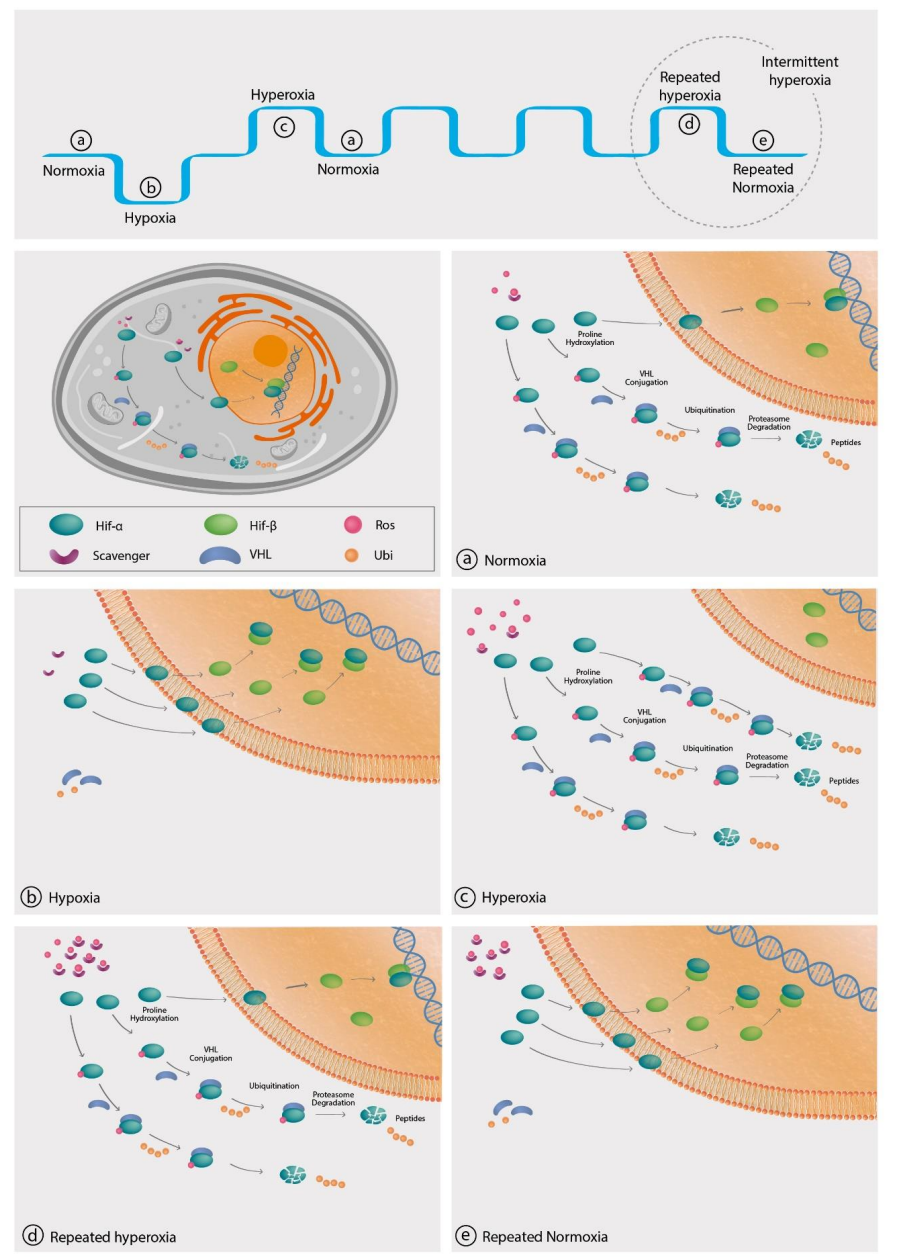

Figure 2. The intracellular cascade of HIF-1 alpha. Legend: HIF-1 is a heterodimer composed of cytoplasmatic HIF- $1 \alpha$ and the nuclear HIF- $1 \beta$ subunits. (a) Under normal oxygen environments, the ratio of ROS/scavenger is high and the free ROS molecules initiate HIF- $1 \alpha$ hydroxylation, HIF- $1 \alpha$ 
subunits become a target for VHLp (von Hippel-Lindau protein) protein which facilitates HIF-1 $\alpha$ subunits ubiquitination and degradation. (b) Under hypoxic conditions, less oxygen and ROS molecules are available, HIF- $1 \alpha$ subunits are not hydrolyzed, and more HIF- $1 \alpha$ subunits penetrate the nucleus to conjugate with HIF-1 $\beta$ subunits and generate the active HIF transcription factor. (c) At the hyperoxic environment, more ROS and oxygen are available; thus more HIF- $1 \alpha$ subunits are hydrolyzed and degraded. (d) The adaptive response to repeated hyperoxia includes increases in the production of scavengers that adjust to the increased ROS generation. Thus, the ROS/scavenger ratio gradually becomes similar to the ratio under normal oxygen environment prior to initiating repeated hyperoxic exposures. (e) Upon return to normoxia, following repeated hyperoxic exposures, the ratio of ROS/scavenger is low due to the fact scavengers elimination half-life $\left(T_{1 / 2}\right)$ is significantly longer than the $\mathrm{T}_{1 / 2}$ of ROS. Accordingly, less HIF- $1 \alpha$ subunits are hydroxylated, and more of them penetrate the nucleus, conjugate with HIF- $1 \beta$ to generate the active HIF, similar to the hypoxic state.

\subsection{Vascular Endothelial Growth Factor (VEGF)}

The VEGF family comprises five members: VEGF-A, placenta growth factor (PGF), VEGF-B, VEGF-C, and VEGF-D. VEGF-A is the most known factor out of the VEGF family. All VEGF factors induce different cellular responses by binding to their respective tyrosine kinase receptors located on the cell surface, inducing the receptors' dimerization, phosphorylation, and activation [22]. VEGF-A production is induced by HIF-1, which in turn activates vascular cells to initiate angiogenesis (the budding of new capillaries from existing vessels) and arteriogenesis (the remodeling of collateral blood vessels to handle the increased flow, bypassing stenotic regions of the original conduit arteries) [11,23]. In addition, the VEGF-A factor induces vasodilatation activity, as well as microvascular permeability increase needed for immediate improvement of tissue ischemia [11]. VEGF-A also stimulates the mobilization of bone marrow-derived angiogenic cells (BMDACs), which in turn migrate to ischemic tissues and participate in angiogenesis and arteriogenesis [11].

\subsection{Sirtuin}

Sirtuins are a family of signaling proteins involved in metabolic regulation. Sirtuins activities include mono-adenosine diphosphate (ADP)-ribosyltransferase or deacylase [24,25]. In mammals, seven sirtuins (SIRT 1-7) have been discovered in different subcellular compartments: SIRT1, SIRT6, and SIRT7 located in the nucleus, SIRT2 in the cytoplasm, and SIRT3, SIRT4, and SIRT5 in the mitochondria [24,25]. SIRT1 is involved in various mechanisms regulating apoptosis, inflammation, and senescence, which are associated with aging-related diseases [14,26-29]. Reductions in the nuclear energy state and nicotinamide adenine dinucleotide $\left(\mathrm{NAD}^{+}\right)$levels decrease the SIRT1 activity, which results in diminished pVHL levels and the stabilization of HIF- $1 \alpha$. Conversely, overexpression of SIRT1 promotes mitochondrial biogenesis by deacetylation, resulting in the activation of HIF-1 $\alpha$ [30]. The decreased level of SIRT1, in both transcriptional and posttranscriptional stages during aging is considered to be a major metabolic pathway that attenuates mitochondrial biogenesis and causes aging-related diseases [14]. In mice models, overexpression of SIRT1 results in delayed aging phenotypes and lifespan extension, whereas inhibition of SIRT1 annuls the lifespan extension [31]. Overexpression of SIRT1 or SIRT6 is protective in many murine disease models, including cancer, type 2 diabetes, and cardiovascular disease [26,28,32-35].

The crosstalk between oxygen- and redox-responsive signal transducers occurs through the SIRT1-HIF interaction $[36,37]$. During hypoxia, the reduced NADH consumption in mitochondria and increased NADH production from glycolysis, causes a reduction of the NAD+/NADH ratio, downregulating SIRT1 transcription. Reduced SIRT1 allows the acetylation of HIF-1 $\alpha$ and its activation and provides a positive feedback loop that maintains high levels of HIF-1 activity during hypoxia. Due to the metabolic crisis in hypoxia, HIF-1 blocks mitochondrial energy metabolism by (1) inducing PDK-1, which inhibits the conversion of pyruvate to acetyl-CoA, by (2) inhibiting mitochondrial biogenesis via c-Myc repression, and by (3) reducing mitochondrial transcription factor A (TFAM), required for replication, transcription, and maintenance of mitochondrial biogenesis [38,39]. 


\subsection{Mitochondria Biogenesis}

Maintaining an adequate mitochondrial population during one's lifetime is crucial. Mitochondrial quality control occurs via the process of mitophagy, degradation of damaged mitochondria, and generation of newly functioning mitochondria by mitochondrial biogenesis, a process in which new mitochondria are formed by growth and division of preexisting mitochondria. Mitochondrial biogenesis is crucial for preserving most human cell integrity, and in recent years, there is growing evidence about their important role in preserving brain functionality and in neurodegenerative diseases [40].

Mitochondrial biogenesis is a complex process requiring coordinated bi-genomic (cellular and mitochondrial DNAs) regulation to execute several distinct processes, including (1) inner and outer mitochondrial membrane synthesis, (2) synthesis of mitochondrial-encoded proteins, (3) synthesis and import of nuclear-encoded mitochondrial proteins, and 4) replication of mitochondrial DNA (mtDNA). Several cell-signaling pathways tightly regulate mitochondrial biogenesis. The AMP-activated kinase (AMPK)-PGC-1a axis and Sirtuin 1 (SIRT1)-PGC-1a are two major pathways that regulate mitochondrial biogenesis. AMPK can be activated by physiological stimuli such as exercise, starvation, and transient hypoxia [41-44].

There is considerable overlap between the AMPK and HIF signaling pathways, as both are involved in energetic stresses, though the relationship is complex, with both opposing and cooperative outcomes depending on the context [45]. As mentioned, AMPK is a potent stimulator of mitochondrial biogenesis, which in normoxic conditions acts to restore ATP homeostasis. However, as detailed above, once AMPK activation occurs under hypoxic conditions, i.e., energetic stress, additional mitochondrial biogenesis, and oxygen consumption would further decrease oxygen availability and worsen the stress. Therefore, HIF signaling under prolonged hypoxia generally acts to decrease mitochondrial biogenesis and mass [45].

\subsection{Stem Cells}

Stem cells (SC) are undifferentiated or partially differentiated cells that can differentiate into various types of cells and divide indefinitely to produce more of the same stem cell. In mammals, the major groups of stem cells include hematopoietic stem cells (HSC), which replenish blood and immune cells, basal cells, which maintain the skin epithelium, and mesenchymal stem cells (MSC), which maintain bone, cartilage, muscle and fat cells. There are also more targeted subgroups of SCs that include neuronal stem cells (NSC) that persist in restricted regions in the adult brain and continue to produce neurons throughout the person's life. NSCs can generate nerve cells and their supporting cells, oligodendrocytes, and astrocytes [46]. In addition to their differentiation capacity, SCs have multipotent properties that include anti-inflammatory effects that make them potential therapeutic candidates for a variety of disorders [47].

During normal conditions, SCs are at a reversible state of quiescence, i.e., at a temporary cell cycle arrest [48]. While being quiescent, they exhibit improved stress resistance and enhanced survival ability. Oxygen has an important role in the regulation of stem cell proliferation and differentiation [48-50]. Short term hypoxia can induce SC proliferation, migration, and differentiation capacity $[48,50]$. In addition, hypoxia also modulates the paracrine activity of MSCs, causing upregulation of various secreted factors, such as VEGF and exosomes, that also have important angiogenesis and anti-inflammatory effects [50-52]. The mechanisms by which hypoxia exerts its effect on cells is mainly regulated by HIF- 1 and related down-cascade protein expression $[48,50]$.

\section{The Hyperoxic Hypoxic Paradox}

As detailed above, hypoxia is the natural trigger for mitochondria metabolic changes via elevated levels of HIF, VEGF, Sirtuin, mitochondria metabolic changes, and SC proliferation, and migration. However, the understanding that at the cellular level, oxygen level fluctuations can trigger a cellular cascade that is usually triggered by hypoxia, allows the use of intermittent hyperoxia to stimulate 
tissue regeneration without the hazardous effects of hypoxia. This is termed the "hyperoxic-hypoxic paradox" (Figure 3).

In clinical practice, intermittent hyperoxia can be generated using hyperbaric oxygen therapy (HBOT). HBOT includes inhaling 100\% oxygen at pressures exceeding 1 atmosphere absolute (ATA) to enhance the amount of oxygen dissolved in the body tissues. During HBOT, the arterial $\mathrm{O}_{2}$ tension typically exceeds $1500 \mathrm{mmHg}$, and levels of $200-400 \mathrm{mmHg}$ occur in tissues. In a normal individual, at a normal environment (20.8\% oxygen at 1ATA), the hemoglobin is almost entirely saturated (94-99\%). Accordingly, when in a hyperbaric environment, the effect is only in the dissolved oxygen. As mentioned above, the dissolved oxygen is the fraction responsible for the diffusion gradient from the capillaries to the mitochondria. In the following part of the article, we will review the cellular cascade induced following repeated transient hyperoxia.

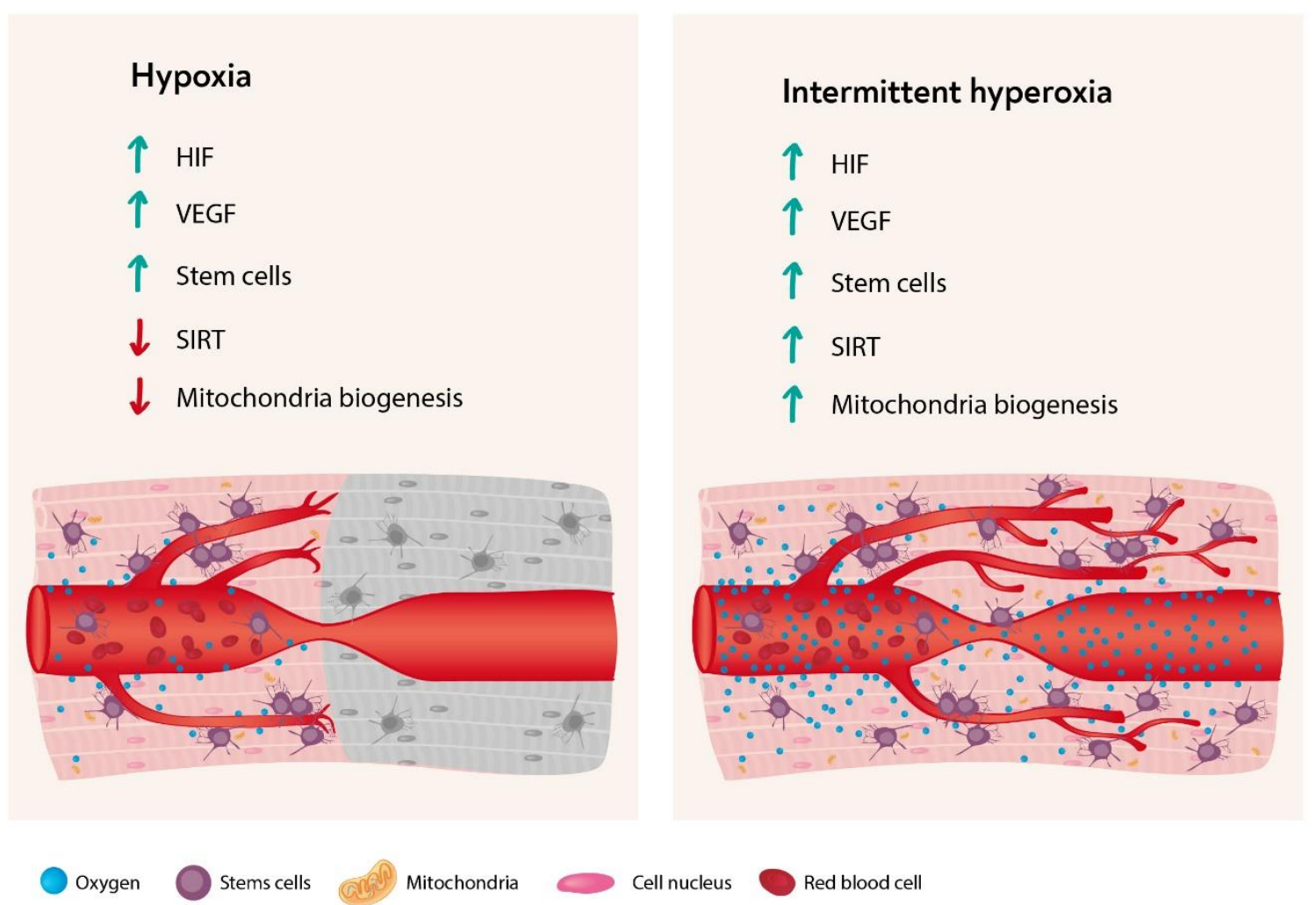

Figure 3. The major cellular response cascade initiated by hypoxia and by intermittent hyperoxia. Legends: HIF: Hypoxic induce factor; VEGF: Vascular endothelial growth factor; SIRT: Sirtuin.

\subsection{Hypoxia-Inducible Factor}

It has been proposed that the relative changes in oxygen availability rather than constant hypoxia or hyperoxia have a more dominant effect on HIF expression [53-55]. According to this hypothesis, the cells interpret the change from normoxia to hypoxia or the change back to normoxia following a hyperoxic exposure as an oxygen shortage and induce HIF-1-regulated gene synthesis [53-55]. Even though there is a growing understanding of the cellular cascade responsible for HIF expression (as detailed below), the precise level of inspired oxygen and the exact timeframe for its iterative administrations are not fully known yet.

The proposed mechanisms for increased HIF availability at normoxia after hyperoxic exposure relates to ROS availability and scavengers, such as the glutathione synthase and superoxide dismutase (SOD) enzymes [53-55]. As detailed above (Figure 2), at normoxic conditions when oxygen and its ROS derivates are available at higher ratios compared to their scavengers, most of the HIF- $1 \alpha$ subunits are hydroxylated by PHD. This results in their ubiquitination by VHLp, and consequently, 
degradation of HIF- $1 \alpha$ in the proteasome. In hypoxia, oxygen and its ROS derivates are less available, the HIF- $1 \alpha$ is not hydroxylated and ubiquitinated by VHLp, and more HIF- $1 \alpha$ is available to enter the nucleus and is dimerized with HIF- $1 \beta$ to form the active HIF promotor. During hyperoxia, increased levels of oxygen availability will enhance the production ROS and the production of ROS scavengers, including glutathione peroxidase, SOD, as well as other ROS scavengers [56-60]. Based on the above cumulative data, our perspective is that this scavenger level increase is limited and gradual following a single hyperoxic exposure, and repeated exposures are required in order to obtain significant scavenging activity (Figure 2). After returning to normoxia from a single hyperoxic exposure, the ROS/scavenging capacity ratio will be high, leading to ubiquitination of all HIF molecules. Upon return to normoxia following repeated hyperoxic exposures, the level of scavengers is increased, along with their inherent elimination half-life $\left(T_{1 / 2}\right)$, which is significantly longer than ROS $T_{1 / 2}$. Thus, the ratio of ROS/(scavenging capacity) will be low, similar to the hypoxic state. With enhanced scavenging capacity, less ROS is available to bind PHD, less degradation of HIF- $\alpha$ subunits, which, in turn, will enter the nucleus to bind to HIF- $1 \beta$ and generate the active HIF gene promotor. Meaning, intermittent hyperoxia generates a hypoxia-mimicking state without hypoxia by decreasing the ratio of ROS/scavenging capacity.

The effect of repeated intermittent hyperoxia by HBOT on HIF expression was demonstrated in different types of organs and cells $[57,58,61,62]$. For example, HBOT can induce HIF expression and its related regenerative cascade in the injured brain [58,63], gastrointestinal tract [57], and liver [61,62]. In addition, HBOT induces the expression of different types of HIF and in different types of stem cells $[59,64]$. The dose-response curve related to the applied pressure, time, and number of HBOT exposures and its relation to HIF expression is still not fully understood, and further studies are needed to find the optimal HBOT protocols. It should be noted that when HBOT is administrated to an ischemic tissue, which overexpresses HIF, tissue hypoxia is being reversed and corrected, accordingly the overexpressed HIF is reduced towards the normalized baseline [65-70]. Moreover, when HBOT is being used as preconditioning therapy for hypoxia (by HIF induction), the tissue will tolerate the ischemic insult better, less ischemic injury induced, and the overall post insult HIF expression will be lower than expected for the same insult [71,72].

\subsection{VEGF and Angiogenesis}

VEGF production is induced by HIF-1 and then goes on to stimulate the cellular processes needed for both angiogenesis and arteriogenesis (as detailed above). VEGF is significantly increased following intermittent hyperoxic exposures, utilizing the HHP. There is growing evidence from preclinical as well as from clinical studies demonstrating that repeated HBOT sessions induce the crucial elements for angiogenesis, VEGF expression, and endothelial progenitor cells (EPCs) [61,73-75]. Unlike VEGF induced under ischemic conditions, VEGF induction under hyperoxic stimuli can facilitate angiogenesis in tissues that are hypoxic/ischemic while breathing normal air. Clinical studies have confirmed that repeated daily HBOT sessions augment the circulating levels of VEGF, EPCs, and improve the blood flow in ischemic areas of patients with chronic peripheral arterial occlusive diseases, with or without non-healing wounds [73-76].

The use of hyperoxic stimuli to induce angiogenesis is crucial for organs that are oxygen- deprived, even at normal conditions such as the human brain $[77,78]$. Therefore, to enable brain angiogenesis and regenerative processes, it is essential to increase oxygen delivery in addition to VEGF induction, which is achieved by cyclic hyperoxic exposure. HBOT can initiate the cellular and vascular repair mechanisms to induce brain angiogenesis and improve cerebral blood flow in damaged brain regions [79-81].

\subsection{Sirtuin}

SIRT1 acts as a metabolic sensor by its ability to deacetylate the mitochondrial biogenesis factor PGC- $1 \alpha$. During hyperoxia, the NAD+/NADH ratio is increased through the Krebs cycle and mitochondrial metabolism, triggering SIRT1 $[82,83]$. SIRT1 is known to deacetylate FOXO3a, which 
induces antioxidant responses via modulating SOD2 and CAT. FOXO3a has further been shown to regulate mitochondrial gene expression, resulting in modulated ROS levels [82]. SIRT1 regulates the acetylation of PGC-1 $\alpha$, a master regulator of mitochondrial biogenesis [83]. SIRT1, along with other sirtulins appears to be an integral part of an important cellular defense mechanism against oxidative stress and ROS formation.

Intermittent hyperoxic exposures, can produce ROS molecules that increase the activity of SIRT-1 inside cells through the activation of mitogen-activated protein kinase (MAPK) [84]. The effect of intermittent hyperoxic exposure was evaluated in several animal models. Yan et al. evaluated the effect of HBOT on SIRT1 in a model of focal cerebral ischemia induced by middle cerebral artery occlusion and also on primary cultured cortical neurons subjected to oxygen-glucose deprivation injury $[84,85]$. Their findings indicate that HBOT's neuroprotective effect is mediated by increased SIRT1 mRNA and protein expression. HBOT's neuroprotection was attenuated by a SIRT1 inhibitor and also in SIRT1 knockdown rats [84]. In another study done in hyperglycemic rats after middle cerebral artery occlusion, HBOT induced activation of ATP/NAD and SIRT1 and SIRT2 pathways resulting in attenuation of hemorrhagic transformation, brain infarction, as well as neurological function improvement [86]. Similar results, indicating that the neuroprotective effects of HBOT are mediated by SIRT1 were demonstrated in middle-aged mice with postoperative cognitive dysfunction [87].

\subsection{Mitochondria}

Any change in the free dissolved oxygen generates a diffusion gradient that directly affects the oxygen delivered and sensed by the mitochondria through the production of ROS signaling molecules. Therefore, intermittent increases in dissolved oxygen generated by HBOT can be compared to "intense interval training" with an expected cumulative effect along with repeated exposures. In a well-designed mice model study, it was demonstrated that adding intermittent hyperbaric exposure to exercise training further improves endurance performance by facilitating oxidative and glycolytic capacities and by increasing the expression of proteins involved in mitochondrial biogenesis in striated muscles [88]. In humans, combining HBOT to an exercise training regimen induces better cardiorespiratory fitness compared to exercise training alone [89].

Regarding the brain, ROS are considered to have significant metabolic effects, and the main source of ROS in the brain is the mitochondria [90]. Normally $1-2 \%$ of the oxygen consumed by the mitochondria is converted to $\mathrm{O}_{2}^{-1}$ and related ROS metabolites such as hydrogen peroxide $\left(\mathrm{H}_{2} \mathrm{O}_{2}\right)$ and peroxynitrite (ONOO-) [91]. $\mathrm{O}_{2}^{-1}$ and related ROS formations increase in proportion to the partial pressure of oxygen, and in high pressure multiplied by the exposure duration. Exposure may induce high neurological activity presented in the form of epileptic seizures [90]. In a study done by Gutsaeva et al., it was demonstrated that pre-convulsive dosages of HBOT induce significant mitochondrial biogenesis in the hippocampus [91]. The cellular response in the hippocampus was mediated by increased NRF-2 gene expression, TFAM gene expression, and mitochondrial gene transcription [91].

In recent years, there is growing evidence about the possibility and the importance of mitochondrial transfer between astrocytes and neurons for proper maintenance of neuronal function and as cell-cell signaling [92,93]. Neurons can release and transfer damaged mitochondria to astrocytes for disposal and recycling [92], and astrocytes can release functional mitochondria that enter into neurons [93]. In a study done by Borlongan and Lippert, it was demonstrated that HBOT could facilitate the transfer of resilient mitochondria from astrocytes to neuronal cells that are more susceptible to inflammation [94]. The mitochondrial transfer from astrocytes to neurons makes the neurons more resilient to inflammatory insults. These findings suggest a new mitochondrial mechanism of neuroglial crosstalk that may contribute to endogenous neuro-protective and neuro-recovery mechanisms induced by HBOT.

\subsection{Stem Cells}

Both hypoxia and intermittent hyperoxia increase HIF and its downstream gene expression, including stem cell factors (SCFs) [95]. Growing data from preclinical and clinical studies demonstrate 
the cumulative effect of repeated intermittent hyperoxia by HBOT on proliferation and mobilization of stem cells [59,96-112]. Clinical studies on patients suffering from diabetic wounds and post-traumatic brain injury have demonstrated that repeated HBOT sessions increase circulating (mobilization) stem cells in correlation with the clinical improvements [96-98].

With regard to subtypes of stem cells, it was demonstrated that HBOT promotes neuronal stem cell proliferation [99-105], stimulates vasculogenic stem cell growth and differentiation [59,106], stimulates colonic stem cells and induces mucosal healing [107], improves the osteogenic properties of mesenchymal stem cells [108,109], and increases the myoblast growth rate and enhances muscle regeneration [110-112].

The main advantage of stimulating stem cells by intermittent hyperoxia instead of hypoxia, is that stem cell proliferation and differentiation, similar to any other regenerative process, is energy-dependent and cannot be accomplished in a hypoxic environment. The fact that oxygen is crucial for stem cells related to regenerative effects has been validated in different studies that compared the results of stem cell injections along with or without HBOT. The potential added value of using HBOT in addition to stem cell injections was seen in a variety of tissues, including brain $[113,114]$, spinal cord and peripheral nerves [115,116], myocardium [117,118], and diabetic wounds [119]. In all those studies, adding HBOT to stem cell injections had synergistic beneficial effects.

\subsection{Oxygen Toxicity}

Although oxygen therapy is considered to be safe, like other active ingredients or drugs, at high dosage, it can be harmful and result in oxygen toxicity. Prolonged exposure to high oxygen pressure with a prolonged imbalance between ROS to scavengers can lead to membrane lipid peroxidation and enzyme inhibition and modulations, most commonly seen in the central nervous system (CNS), that lead to alterations in neuronal metabolism and its related electrical activity [120]. As was first suggested in 1878, breathing hyperbaric oxygen can culminate in grand mal seizures [121]. Another organ that is relatively sensitive to oxygen toxicity is the lung. Pulmonary oxygen toxicity can be manifested by chest tightness, cough, and a reversible decline of pulmonary function [122].

Both CNS and pulmonary toxicity depend upon the partial pressure of oxygen and the duration of exposure [123]. Accordingly, the new HBOT protocol used today includes repeated daily sessions limited to 60-90 min with oxygen partial pressure not exceeding 2.4 ATA, as well as air brakes every 20-30 min. Using those new protocols, HBOT is considered to be safe, while both pulmonary and oxygen toxicity are very rare [124-126]. In a recent analysis of 62,614 hyperbaric sessions, the overall incidence of seizures during hyperbaric sessions was $0.011 \%(1: 8,945$ sessions $)$ [124,125]. In addition, in patients without chronic lung diseases, the currently used HBOT protocols do not cause any pulmonary toxicity or changes in pulmonary functions following 60 repeated exposures [126].

\section{Summary}

As in Albert Einstein's "theory of relativity" that explains the basic physical aspects of our cosmos, relatively can also be found in the micro-cosmos, i.e., the microenvironmental interpretation at the cellular level. As summarized in Figure 3, most of the cellular cascades initiated by hypoxia can be induced by intermittent hyperoxia, the so-called "hyperoxic-hypoxic paradox". HIF, VEGF, SIRT, mitochondrial biogenesis, and stem cell proliferation and migration could all be induced by "biological fooling" the cells with certain protocols of repeated intermittent hyperoxia. Even though the exact dose response-curve has yet to be discovered in clinical practice, certain HBOT protocols have already demonstrated induction of damaged tissue regeneration.

Funding: The study was funded by a research grant from the Research fund of the Shamir medical center.

Acknowledgments: We would like to thank Mechael Kanovsky for his editing of this manuscript.

Conflicts of Interest: AH works for AVIV Scientific LTD. ES is a shareholder in AVIV Scientific LTD. Aviv Scientific LTD had no role in the design, execution, interpretation or writing of the study. 


\section{References}

1. Berner, R.A. Atmospheric oxygen over Phanerozoic time. Proc. Natl. Acad. Sci. USA 1999, 96, $10955-10957$. [CrossRef] [PubMed]

2. Butterfield, N.J. Oxygen, animals and oceanic ventilation: An alternative view. Geobiology 2009, 7, 1-7. [CrossRef] [PubMed]

3. Trayhurn, P. Oxygen-A Critical, but Overlooked, Nutrient. Front. Nutr. 2019, 6, 10. [CrossRef] [PubMed]

4. Collins, J.A.; Rudenski, A.; Gibson, J.; Howard, L.; O'Driscoll, R. Relating oxygen partial pressure, saturation and content: The haemoglobin-oxygen dissociation curve. Breathe (Sheff) 2015, 11, 194-201. [CrossRef]

5. Echevarria, M.; Munoz-Cabello, A.M.; Sanchez-Silva, R.; Toledo-Aral, J.J.; Lopez-Barneo, J. Development of cytosolic hypoxia and hypoxia-inducible factor stabilization are facilitated by aquaporin-1 expression. J. Biol. Chem. 2007, 282, 30207-30215. [CrossRef]

6. Ward, J.P. Oxygen sensors in context. Biochim. Biophys. Acta 2008, 1777, 1-14. [CrossRef]

7. Palmeira, C.M.; Teodoro, J.S.; Amorim, J.A.; Steegborn, C.; Sinclair, D.A.; Rolo, A.P. Mitohormesis and metabolic health: The interplay between ROS, cAMP and sirtuins. Free Radic. Biol. Med. 2019, 141, $483-491$. [CrossRef]

8. Waypa, G.B.; Smith, K.A.; Schumacker, P.T. O2 sensing, mitochondria and ROS signaling: The fog is lifting. Mol. Asp. Med. 2016, 47-48, 76-89. [CrossRef]

9. Roman, R.J. P-450 metabolites of arachidonic acid in the control of cardiovascular function. Physiol. Rev. 2002, 82, 131-185. [CrossRef]

10. Michaelis, U.R.; Fisslthaler, B.; Barbosa-Sicard, E.; Falck, J.R.; Fleming, I.; Busse, R. Cytochrome P450 epoxygenases 2C8 and 2C9 are implicated in hypoxia-induced endothelial cell migration and angiogenesis. J. Cell Sci. 2005, 118, 5489-5498. [CrossRef]

11. Semenza, G.L. Oxygen sensing, homeostasis, and disease. N. Engl. J. Med. 2011, 365, 537-547. [CrossRef] [PubMed]

12. Choudhury, R. Hypoxia and hyperbaric oxygen therapy: A review. Int. J. Gen. Med. 2018, 11, 431-442. [CrossRef] [PubMed]

13. Minet, E.; Ernest, I.; Michel, G.; Roland, I.; Remacle, J.; Raes, M.; Michiels, C. HIF1A gene transcription is dependent on a core promoter sequence encompassing activating and inhibiting sequences located upstream from the transcription initiation site and cis elements located within the 5'UTR. BioChem. Biophys. Res. Commun. 1999, 261, 534-540. [CrossRef] [PubMed]

14. Yeo, E.J. Hypoxia and aging. Exp. Mol. Med. 2019, 51, 1-15. [CrossRef] [PubMed]

15. Haase, V.H. Hypoxic regulation of erythropoiesis and iron metabolism. Am. J. Physiol. Ren. Physiol. 2010, 299, F1-F13. [CrossRef]

16. Zhang, Y.; Strehin, I.; Bedelbaeva, K.; Gourevitch, D.; Clark, L.; Leferovich, J.; Messersmith, P.B.; Heber-Katz, E. Drug-induced regeneration in adult mice. Sci. Transl. Med. 2015, 7, 290ra92. [CrossRef]

17. Adamcio, B.; Sperling, S.; Hagemeyer, N.; Walkinshaw, G.; Ehrenreich, H. Hypoxia inducible factor stabilization leads to lasting improvement of hippocampal memory in healthy mice. Behav. Brain Res. 2010, 208, 80-84. [CrossRef]

18. Schreiber, T.; Salhofer, L.; Quinting, T.; Fandrey, J. Things get broken: The hypoxia-inducible factor prolyl hydroxylases in ischemic heart disease. Basic Res. Cardiol. 2019, 114, 16. [CrossRef]

19. Xing, J.; Lu, J. HIF-1alpha Activation Attenuates IL-6 and TNF-alpha Pathways in Hippocampus of Rats Following Transient Global Ischemia. Cell. Physiol. BioChem. 2016, 39, 511-520. [CrossRef]

20. Chen, H.; Li, J.; Liang, S.; Lin, B.; Peng, Q.; Zhao, P.; Cui, J.; Rao, Y. Effect of hypoxia-inducible factor-1/vascular endothelial growth factor signaling pathway on spinal cord injury in rats. Exp. Ther. Med. 2017, 13, 861-866. [CrossRef]

21. Kido, M.; Du, L.; Sullivan, C.C.; Li, X.; Deutsch, R.; Jamieson, S.W.; Thistlethwaite, P.A. Hypoxia-inducible factor 1-alpha reduces infarction and attenuates progression of cardiac dysfunction after myocardial infarction in the mouse. J. Am. Coll. Cardiol. 2005, 46, 2116-2124. [CrossRef] [PubMed]

22. Karkkainen, M.J.; Petrova, T.V. Vascular endothelial growth factor receptors in the regulation of angiogenesis and lymphangiogenesis. Oncogene 2000, 19, 5598-5605. [CrossRef] [PubMed] 
23. van Weel, V.; van Tongeren, R.B.; van Hinsbergh, V.W.; van Bockel, J.H.; Quax, P.H. Vascular growth in ischemic limbs: A review of mechanisms and possible therapeutic stimulation. Ann. Vasc. Surg. 2008, 22, 582-597. [CrossRef] [PubMed]

24. Dai, H.; Sinclair, D.A.; Ellis, J.L.; Steegborn, C. Sirtuin activators and inhibitors: Promises, achievements, and challenges. Pharmacol. Ther. 2018, 188, 140-154. [CrossRef] [PubMed]

25. Ye, X.; Li, M.; Hou, T.; Gao, T.; Zhu, W.G.; Yang, Y. Sirtuins in glucose and lipid metabolism. Oncotarget 2017, 8, 1845-1859. [CrossRef] [PubMed]

26. Poulose, N.; Raju, R. Sirtuin regulation in aging and injury. Biochim. Biophys. Acta 2015, 1852, $2442-2455$. [CrossRef]

27. Bai, X.; Yao, L.; Ma, X.; Xu, X. Small Molecules as SIRT Modulators. Mini Rev. Med. Chem. 2018, 18, 1151-1157. [CrossRef]

28. Matsushima, S.; Sadoshima, J. The role of sirtuins in cardiac disease. Am. J. Physiol. Heart Circ. Physiol. 2015, 309, H1375-H1389. [CrossRef]

29. Zhang, H.N.; Dai, Y.; Zhang, C.H.; Omondi, A.M.; Ghosh, A.; Khanra, I.; Chakraborty, M.; Yu, X.B.; Liang, J. Sirtuins family as a target in endothelial cell dysfunction: Implications for vascular ageing. Biogerontology 2020. [CrossRef]

30. Gomes, A.P.; Price, N.L.; Ling, A.J.; Moslehi, J.J.; Montgomery, M.K.; Rajman, L.; White, J.P.; Teodoro, J.S.; Wrann, C.D.; Hubbard, B.P.; et al. Declining $\mathrm{NAD}(+)$ induces a pseudohypoxic state disrupting nuclear-mitochondrial communication during aging. Cell 2013, 155, 1624-1638. [CrossRef]

31. Satoh, A.; Brace, C.S.; Rensing, N.; Cliften, P.; Wozniak, D.F.; Herzog, E.D.; Yamada, K.A.; Imai, S. Sirt1 extends life span and delays aging in mice through the regulation of Nk2 homeobox 1 in the DMH and LH. Cell Metab. 2013, 18, 416-430. [CrossRef]

32. Banks, A.S.; Kon, N.; Knight, C.; Matsumoto, M.; Gutierrez-Juarez, R.; Rossetti, L.; Gu, W.; Accili, D. SirT1 gain of function increases energy efficiency and prevents diabetes in mice. Cell Metab. 2008, 8, 333-341. [CrossRef] [PubMed]

33. Firestein, R.; Blander, G.; Michan, S.; Oberdoerffer, P.; Ogino, S.; Campbell, J.; Bhimavarapu, A.; Luikenhuis, S.; de Cabo, R.; Fuchs, C.; et al. The SIRT1 deacetylase suppresses intestinal tumorigenesis and colon cancer growth. PLoS ONE 2008, 3, e2020. [CrossRef] [PubMed]

34. Yamamoto, T.; Sadoshima, J. Protection of the heart against ischemia/reperfusion by silent information regulator 1. Trends Cardiovasc. Med. 2011, 21, 27-32. [CrossRef] [PubMed]

35. Pfluger, P.T.; Herranz, D.; Velasco-Miguel, S.; Serrano, M.; Tschop, M.H. Sirt1 protects against high-fat diet-induced metabolic damage. Proc. Natl. Acad. Sci. USA 2008, 105, 9793-9798. [CrossRef] [PubMed]

36. Lim, J.H.; Lee, Y.M.; Chun, Y.S.; Chen, J.; Kim, J.E.; Park, J.W. Sirtuin 1 modulates cellular responses to hypoxia by deacetylating hypoxia-inducible factor 1alpha. Mol. Cell 2010, 38, 864-878. [CrossRef]

37. Chen, R.; Dioum, E.M.; Hogg, R.T.; Gerard, R.D.; Garcia, J.A. Hypoxia increases sirtuin 1 expression in a hypoxia-inducible factor-dependent manner. J. Biol. Chem. 2011, 286, 13869-13878. [CrossRef]

38. Kim, J.W.; Tchernyshyov, I.; Semenza, G.L.; Dang, C.V. HIF-1-mediated expression of pyruvate dehydrogenase kinase: A metabolic switch required for cellular adaptation to hypoxia. Cell Metab. 2006, 3, 177-185. [CrossRef]

39. Zhang, H.; Gao, P.; Fukuda, R.; Kumar, G.; Krishnamachary, B.; Zeller, K.I.; Dang, C.V.; Semenza, G.L. HIF-1 inhibits mitochondrial biogenesis and cellular respiration in VHL-deficient renal cell carcinoma by repression of C-MYC activity. Cancer Cell 2007, 11, 407-420. [CrossRef]

40. Uittenbogaard, M.; Chiaramello, A. Mitochondrial biogenesis: A therapeutic target for neurodevelopmental disorders and neurodegenerative diseases. Curr. Pharm. Des. 2014, 20, 5574-5593. [CrossRef]

41. Zhang, H.; Liu, B.; Li, T.; Zhu, Y.; Luo, G.; Jiang, Y.; Tang, F.; Jian, Z.; Xiao, Y. AMPK activation serves a critical role in mitochondria quality control via modulating mitophagy in the heart under chronic hypoxia. Int. J. Mol. Med. 2018, 41, 69-76. [CrossRef] [PubMed]

42. Li, P.A.; Hou, X.; Hao, S. Mitochondrial biogenesis in neurodegeneration. J. Neurosci. Res. 2017, 95, $2025-2029$. [CrossRef] [PubMed]

43. Yin, W.; Signore, A.P.; Iwai, M.; Cao, G.; Gao, Y.; Chen, J. Rapidly increased neuronal mitochondrial biogenesis after hypoxic-ischemic brain injury. Stroke 2008, 39, 3057-3063. [CrossRef] [PubMed]

44. Marsin, A.S.; Bertrand, L.; Rider, M.H.; Deprez, J.; Beauloye, C.; Vincent, M.F.; Van den Berghe, G.; Carling, D.; Hue, L. Phosphorylation and activation of heart PFK-2 by AMPK has a role in the stimulation of glycolysis during ischaemia. Curr. Biol. 2000, 10, 1247-1255. [CrossRef] 
45. Thomas, L.W.; Ashcroft, M. Exploring the molecular interface between hypoxia-inducible factor signalling and mitochondria. Cell. Mol. Life Sci. 2019, 76, 1759-1777. [CrossRef] [PubMed]

46. De Gioia, R.; Biella, F.; Citterio, G.; Rizzo, F.; Abati, E.; Nizzardo, M.; Bresolin, N.; Comi, G.P.; Corti, S. Neural Stem Cell Transplantation for Neurodegenerative Diseases. Int. J. Mol. Sci. 2020, 21, 3103. [CrossRef]

47. Pittenger, M.F.; Discher, D.E.; Peault, B.M.; Phinney, D.G.; Hare, J.M.; Caplan, A.I. Mesenchymal stem cell perspective: Cell biology to clinical progress. NPJ Regen. Med. 2019, 4, 22. [CrossRef]

48. Mohammad, K.; Dakik, P.; Medkour, Y.; Mitrofanova, D.; Titorenko, V.I. Quiescence Entry, Maintenance, and Exit in Adult Stem Cells. Int. J. Mol. Sci. 2019, 20, 2158. [CrossRef]

49. Alijani, N.; Johari, B.; Moradi, M.; Kadivar, M. A review on transcriptional regulation responses to hypoxia in mesenchymal stem cells. Cell Biol. Int. 2019, 44, 14-26. [CrossRef]

50. Das, R.; Jahr, H.; van Osch, G.J.; Farrell, E. The role of hypoxia in bone marrow-derived mesenchymal stem cells: Considerations for regenerative medicine approaches. Tissue Eng. Part B Rev. 2010, 16, 159-168. [CrossRef]

51. Han, Y.; Ren, J.; Bai, Y.; Pei, X.; Han, Y. Exosomes from hypoxia-treated human adipose-derived mesenchymal stem cells enhance angiogenesis through VEGF/VEGF-R. Int. J. Biochem. Cell Biol. 2019, 109, 59-68. [CrossRef] [PubMed]

52. Cui, G.H.; Wu, J.; Mou, F.F.; Xie, W.H.; Wang, F.B.; Wang, Q.L.; Fang, J.; Xu, Y.W.; Dong, Y.R.; Liu, J.R.; et al. Exosomes derived from hypoxia-preconditioned mesenchymal stromal cells ameliorate cognitive decline by rescuing synaptic dysfunction and regulating inflammatory responses in APP/PS1 mice. FASEB J. 2018, 32, 654-668. [CrossRef] [PubMed]

53. Rocco, M.; D'Itri, L.; De Bels, D.; Corazza, F.; Balestra, C. The "normobaric oxygen paradox": A new tool for the anesthetist? Minerva Anestesiol 2014, 80, 366-372. [PubMed]

54. Cimino, F.; Balestra, C.; Germonpre, P.; De Bels, D.; Tillmans, F.; Saija, A.; Speciale, A.; Virgili, F. Pulsed high oxygen induces a hypoxic-like response in human umbilical endothelial cells and in humans. J. Appl. Physiol. 2012, 113, 1684-1689. [CrossRef] [PubMed]

55. Balestra, C.; Germonpre, P. Hypoxia, a multifaceted phenomenon: The example of the "normobaric oxygen paradox". Eur. J. Appl. Physiol. 2012, 112, 4173-4175. [CrossRef]

56. Haddad, J.J. Antioxidant and prooxidant mechanisms in the regulation of redox(y)-sensitive transcription factors. Cell. Signal. 2002, 14, 879-897. [CrossRef]

57. Novak, S.; Drenjancevic, I.; Vukovic, R.; Kellermayer, Z.; Cosic, A.; Tolusic Levak, M.; Balogh, P.; Culo, F.; Mihalj, M. Anti-Inflammatory Effects of Hyperbaric Oxygenation during DSS-Induced Colitis in BALB/c Mice Include Changes in Gene Expression of HIF-1alpha, Proinflammatory Cytokines, and Antioxidative Enzymes. Mediat. Inflamm. 2016, 2016, 7141430. [CrossRef]

58. Hu, Q.; Liang, X.; Chen, D.; Chen, Y.; Doycheva, D.; Tang, J.; Tang, J.; Zhang, J.H. Delayed hyperbaric oxygen therapy promotes neurogenesis through reactive oxygen species/hypoxia-inducible factor-1alpha/beta-catenin pathway in middle cerebral artery occlusion rats. Stroke 2014, 45, 1807-1814. [CrossRef]

59. Milovanova, T.N.; Bhopale, V.M.; Sorokina, E.M.; Moore, J.S.; Hunt, T.K.; Hauer-Jensen, M.; Velazquez, O.C.; Thom, S.R. Hyperbaric oxygen stimulates vasculogenic stem cell growth and differentiation in vivo. J. Appl. Physiol. 2009, 106, 711-728. [CrossRef]

60. Yu, Q.H.; Zhang, P.X.; Liu, Y.; Liu, W.; Yin, N. Hyperbaric oxygen preconditioning protects the lung against acute pancreatitis induced injury via attenuating inflammation and oxidative stress in a nitric oxide dependent manner. BioChem. Biophys. Res. Commun. 2016, 478, 93-100. [CrossRef]

61. Ren, P.; Kang, Z.; Gu, G.; Liu, Y.; Xu, W.; Tao, H.; Zhang, J.H.; Sun, X.; Ji, H. Hyperbaric oxygen preconditioning promotes angiogenesis in rat liver after partial hepatectomy. Life Sci. 2008, 83, 236-241. [CrossRef] [PubMed]

62. Salhanick, S.D.; Belikoff, B.; Orlow, D.; Holt, D.; Reenstra, W.; Buras, J.A. Hyperbaric oxygen reduces acetaminophen toxicity and increases HIF-1alpha expression. Acad. Emerg. Med. 2006, 13, 707-714. [CrossRef] [PubMed]

63. Peng, Z.; Ren, P.; Kang, Z.; Du, J.; Lian, Q.; Liu, Y.; Zhang, J.H.; Sun, X. Up-regulated HIF-1alpha is involved in the hypoxic tolerance induced by hyperbaric oxygen preconditioning. Brain Res. 2008, 1212, 71-78. [CrossRef] [PubMed]

64. Milosevic, J.; Adler, I.; Manaenko, A.; Schwarz, S.C.; Walkinshaw, G.; Arend, M.; Flippin, L.A.; Storch, A.; Schwarz, J. Non-hypoxic stabilization of hypoxia-inducible factor alpha (HIF-alpha): Relevance in neural progenitor/stem cells. Neurotox. Res. 2009, 15, 367-380. [CrossRef] [PubMed] 
65. Calvert, J.W.; Cahill, J.; Yamaguchi-Okada, M.; Zhang, J.H. Oxygen treatment after experimental hypoxia-ischemia in neonatal rats alters the expression of HIF-1alpha and its downstream target genes. J. Appl. Physiol. 2006, 101, 853-865. [CrossRef]

66. Bai, X.; Sun, B.; Pan, S.; Jiang, H.; Wang, F.; Krissansen, G.W.; Sun, X. Down-regulation of hypoxia-inducible factor-1alpha by hyperbaric oxygen attenuates the severity of acute pancreatitis in rats. Pancreas 2009, 38, 515-522. [CrossRef]

67. Li, Z.; Li, M.; Li, X.; Zhang, M.; Zhao, Y.; Ren, W.; Cheng, J.; Wang, X. Hyperbaric oxygen inhibits venous neointimal hyperplasia following arteriovenous fistulization. Int. J. Mol. Med. 2017, 39, 1299-1306. [CrossRef]

68. Zhang, Q.; Chang, Q.; Cox, R.A.; Gong, X.; Gould, L.J. Hyperbaric oxygen attenuates apoptosis and decreases inflammation in an ischemic wound model. J. Investig. Dermatol. 2008, 128, 2102-2112. [CrossRef]

69. Sun, L.; Marti, H.H.; Veltkamp, R. Hyperbaric oxygen reduces tissue hypoxia and hypoxia-inducible factor-1 alpha expression in focal cerebral ischemia. Stroke 2008, 39, 1000-1006. [CrossRef]

70. Li, Y.; Zhou, C.; Calvert, J.W.; Colohan, A.R.; Zhang, J.H. Multiple effects of hyperbaric oxygen on the expression of HIF-1 alpha and apoptotic genes in a global ischemia-hypotension rat model. Exp. Neurol. 2005, 191, 198-210. [CrossRef]

71. Duan, S.; Shao, G.; Yu, L.; Ren, C. Angiogenesis contributes to the neuroprotection induced by hyperbaric oxygen preconditioning against focal cerebral ischemia in rats. Int. J. Neurosci. 2015, 125, 625-634. [CrossRef] [PubMed]

72. Gu, G.J.; Li, Y.P.; Peng, Z.Y.; Xu, J.J.; Kang, Z.M.; Xu, W.G.; Tao, H.Y.; Ostrowski, R.P.; Zhang, J.H.; Sun, X.J. Mechanism of ischemic tolerance induced by hyperbaric oxygen preconditioning involves upregulation of hypoxia-inducible factor-1alpha and erythropoietin in rats. J. Appl. Physiol. 2008, 104, 1185-1191. [CrossRef] [PubMed]

73. Lin, P.Y.; Sung, P.H.; Chung, S.Y.; Hsu, S.L.; Chung, W.J.; Sheu, J.J.; Hsueh, S.K.; Chen, K.H.; Wu, R.W.; Yip, H.K. Hyperbaric Oxygen Therapy Enhanced Circulating Levels of Endothelial Progenitor Cells and Angiogenesis Biomarkers, Blood Flow, in Ischemic Areas in Patients with Peripheral Arterial Occlusive Disease. J. Clin Med. 2018, 7, 548. [CrossRef] [PubMed]

74. Anguiano-Hernandez, Y.M.; Contreras-Mendez, L.; de Los Angeles Hernandez-Cueto, M.; Muand Oz-Medina, J.E.; Santillan-Verde, M.A.; Barbosa-Cabrera, R.E.; Delgado-Quintana, C.A.; Trejo-Rosas, S.; Santacruz-Tinoco, C.E.; Gonzalez-Ibarra, J.; et al. Modification of HIF-1alpha, NF-akappaB, IGFBP-3, VEGF and adiponectin in diabetic foot ulcers treated with hyperbaric oxygen. Undersea Hyperb. Med. 2019, 46, $35-44$.

75. Hsu, S.L.; Yin, T.C.; Shao, P.L.; Chen, K.H.; Wu, R.W.; Chen, C.C.; Lin, P.Y.; Chung, S.Y.; Sheu, J.J.; Sung, P.H.; et al. Hyperbaric oxygen facilitates the effect of endothelial progenitor cell therapy on improving outcome of rat critical limb ischemia. Am. J. Transl. Res. 2019, 11, 1948-1964.

76. Sureda, A.; Batle, J.M.; Martorell, M.; Capo, X.; Tejada, S.; Tur, J.A.; Pons, A. Antioxidant Response of Chronic Wounds to Hyperbaric Oxygen Therapy. PLoS ONE 2016, 11, e0163371. [CrossRef]

77. Hadanny, A.; Efrati, S. Oxygen-A limiting factor for brain recovery. Crit. Care 2015, 19, 307. [CrossRef]

78. Vadas, D.; Kalichman, L.; Hadanny, A.; Efrati, S. Hyperbaric Oxygen Environment Can Enhance Brain Activity and Multitasking Performance. Front. Integr. Neurosci. 2017, 11, 25. [CrossRef]

79. Efrati, S.; Ben-Jacob, E. Reflections on the neurotherapeutic effects of hyperbaric oxygen. Expert Rev. Neurother. 2014, 14, 233-236. [CrossRef]

80. Tal, S.; Hadanny, A.; Berkovitz, N.; Sasson, E.; Ben-Jacob, E.; Efrati, S. Hyperbaric oxygen may induce angiogenesis in patients suffering from prolonged post-concussion syndrome due to traumatic brain injury. Restor. Neurol. Neurosci. 2015, 33, 943-951. [CrossRef]

81. Tal, S.; Hadanny, A.; Sasson, E.; Suzin, G.; Efrati, S. Hyperbaric Oxygen Therapy Can Induce Angiogenesis and Regeneration of Nerve Fibers in Traumatic Brain Injury Patients. Front. Hum. Neurosci. 2017, 11, 508. [CrossRef] [PubMed]

82. Yao, H.; Chung, S.; Hwang, J.W.; Rajendrasozhan, S.; Sundar, I.K.; Dean, D.A.; McBurney, M.W.; Guarente, L.; $\mathrm{Gu}, \mathrm{W} . ;$ Ronty, M.; et al. SIRT1 protects against emphysema via FOXO3-mediated reduction of premature senescence in mice. J. Clin. Investig. 2012, 122, 2032-2045. [CrossRef] [PubMed]

83. Nemoto, S.; Fergusson, M.M.; Finkel, T. SIRT1 functionally interacts with the metabolic regulator and transcriptional coactivator PGC-1\{alpha\}. J. Biol. Chem. 2005, 280, 16456-16460. [CrossRef] [PubMed] 
84. Yan, W.; Fang, Z.; Yang, Q.; Dong, H.; Lu, Y.; Lei, C.; Xiong, L. SirT1 mediates hyperbaric oxygen preconditioning-induced ischemic tolerance in rat brain. J. Cereb. Blood Flow Metab. 2013, 33, 396-406. [CrossRef] [PubMed]

85. Xue, F.; Huang, J.W.; Ding, P.Y.; Zang, H.G.; Kou, Z.J.; Li, T.; Fan, J.; Peng, Z.W.; Yan, W.J. Nrf2/antioxidant defense pathway is involved in the neuroprotective effects of Sirt1 against focal cerebral ischemia in rats after hyperbaric oxygen preconditioning. Behav. Brain Res. 2016, 309, 1-8. [CrossRef] [PubMed]

86. Hu, Q.; Manaenko, A.; Bian, H.; Guo, Z.; Huang, J.L.; Guo, Z.N.; Yang, P.; Tang, J.; Zhang, J.H. Hyperbaric Oxygen Reduces Infarction Volume and Hemorrhagic Transformation Through ATP/NAD(+)/Sirt1 Pathway in Hyperglycemic Middle Cerebral Artery Occlusion Rats. Stroke 2017, 48, 1655-1664. [CrossRef]

87. Hong-Qiang, H.; Mang-Qiao, S.; Fen, X.; Shan-Shan, L.; Hui-Juan, C.; Wu-Gang, H.; Wen-Jun, Y.; Zheng-Wu, P. Sirt1 mediates improvement of isoflurane-induced memory impairment following hyperbaric oxygen preconditioning in middle-aged mice. Physiol. Behav. 2018, 195, 1-8. [CrossRef]

88. Suzuki, J. Endurance performance is enhanced by intermittent hyperbaric exposure via up-regulation of proteins involved in mitochondrial biogenesis in mice. Physiol. Rep. 2017, 5, e13349. [CrossRef]

89. DeCato, T.W.; Bradley, S.M.; Wilson, E.L.; Harlan, N.P.; Villela, M.A.; Weaver, L.K.; Hegewald, M.J. Effects of sprInt. interval training on cardiorespiratory fitness while in a hyperbaric oxygen environment. Undersea Hyperb. Med. 2019, 46, 117-124.

90. Chavko, M.; Harabin, A.L. Regional lipid peroxidation and protein oxidation in rat brain after hyperbaric oxygen exposure. Free Radic. Biol. Med. 1996, 20, 973-978. [CrossRef]

91. Gutsaeva, D.R.; Suliman, H.B.; Carraway, M.S.; Demchenko, I.T.; Piantadosi, C.A. Oxygen-induced mitochondrial biogenesis in the rat hippocampus. Neuroscience 2006, 137, 493-504. [CrossRef] [PubMed]

92. Davis, C.H.; Kim, K.Y.; Bushong, E.A.; Mills, E.A.; Boassa, D.; Shih, T.; Kinebuchi, M.; Phan, S.; Zhou, Y.; Bihlmeyer, N.A.; et al. Transcellular degradation of axonal mitochondria. Proc. Natl. Acad. Sci. USA 2014, 111, 9633-9638. [CrossRef] [PubMed]

93. Hayakawa, K.; Esposito, E.; Wang, X.; Terasaki, Y.; Liu, Y.; Xing, C.; Ji, X.; Lo, E.H. Transfer of mitochondria from astrocytes to neurons after stroke. Nature 2016, 535, 551-555. [CrossRef]

94. Lippert, T.; Borlongan, C.V. Prophylactic treatment of hyperbaric oxygen treatment mitigates inflammatory response via mitochondria transfer. CNS Neurosci. Ther. 2019, 25, 815-823. [CrossRef] [PubMed]

95. Han, Z.B.; Ren, H.; Zhao, H.; Chi, Y.; Chen, K.; Zhou, B.; Liu, Y.J.; Zhang, L.; Xu, B.; Liu, B.; et al. Hypoxia-inducible factor (HIF)-1 alpha directly enhances the transcriptional activity of stem cell factor (SCF) in response to hypoxia and epidermal growth factor (EGF). Carcinogenesis 2008, 29, 1853-1861. [CrossRef]

96. Shandley, S.; Wolf, E.G.; Schubert-Kappan, C.M.; Baugh, L.M.; Richards, M.F.; Prye, J.; Arizpe, H.M.; Kalns, J. Increased circulating stem cells and better cognitive performance in traumatic brain injury subjects following hyperbaric oxygen therapy. Undersea Hyperb. Med. 2017, 44, 257-269. [CrossRef]

97. Heyboer, M., 3rd; Milovanova, T.N.; Wojcik, S.; Grant, W.; Chin, M.; Hardy, K.R.; Lambert, D.S.; Logue, C.; Thom, S.R. CD34+/CD45-dim stem cell mobilization by hyperbaric oxygen-Changes with oxygen dosage. Stem Cell Res. 2014, 12, 638-645. [CrossRef]

98. Thom, S.R.; Bhopale, V.M.; Velazquez, O.C.; Goldstein, L.J.; Thom, L.H.; Buerk, D.G. Stem cell mobilization by hyperbaric oxygen. Am. J. Physiol. Heart Circ. Physiol. 2006, 290, H1378-H1386. [CrossRef]

99. Wang, X.L.; Yang, Y.J.; Xie, M.; Yu, X.H.; Liu, C.T.; Wang, X. Proliferation of neural stem cells correlates with Wnt-3 protein in hypoxic-ischemic neonate rats after hyperbaric oxygen therapy. Neuroreport 2007, 18, 1753-1756. [CrossRef]

100. Feng, Z.; Liu, J.; Ju, R. Hyperbaric oxygen treatment promotes neural stem cell proliferation in the subventricular zone of neonatal rats with hypoxic-ischemic brain damage. Neural Regen. Res. 2013, 8, 1220-1227.

101. Yang, Y.; Wei, H.; Zhou, X.; Zhang, F.; Wang, C. Hyperbaric oxygen promotes neural stem cell proliferation by activating vascular endothelial growth factor/extracellular signal-regulated kinase signaling after traumatic brain injury. Neuroreport 2017, 28, 1232-1238. [CrossRef] [PubMed]

102. Zhang, T.; Yang, Q.W.; Wang, S.N.; Wang, J.Z.; Wang, Q.; Wang, Y.; Luo, Y.J. Hyperbaric oxygen therapy improves neurogenesis and brain blood supply in piriform cortex in rats with vascular dementia. Brain Inj. 2010, 24, 1350-1357. [CrossRef] [PubMed] 
103. Yang, Y.J.; Wang, X.L.; Yu, X.H.; Wang, X.; Xie, M.; Liu, C.T. Hyperbaric oxygen induces endogenous neural stem cells to proliferate and differentiate in hypoxic-ischemic brain damage in neonatal rats. Undersea Hyperb. Med. 2008, 35, 113-129. [PubMed]

104. Lee, Y.S.; Chio, C.C.; Chang, C.P.; Wang, L.C.; Chiang, P.M.; Niu, K.C.; Tsai, K.J. Long course hyperbaric oxygen stimulates neurogenesis and attenuates inflammation after ischemic stroke. Mediat. Inflamm. 2013, 2013, 512978. [CrossRef]

105. Wei, L.; Wang, J.; Cao, Y.; Ren, Q.; Zhao, L.; Li, X.; Wang, J. Hyperbaric oxygenation promotes neural stem cell proliferation and protects the learning and memory ability in neonatal hypoxic-ischemic brain damage. Int. J. Clin. Exp. Pathol. 2015, 8, 1752-1759.

106. Thom, S.R.; Milovanova, T.N.; Yang, M.; Bhopale, V.M.; Sorokina, E.M.; Uzun, G.; Malay, D.S.; Troiano, M.A.; Hardy, K.R.; Lambert, D.S.; et al. Vasculogenic stem cell mobilization and wound recruitment in diabetic patients: Increased cell number and intracellular regulatory protein content associated with hyperbaric oxygen therapy. Wound Repair Regen. 2011, 19, 149-161. [CrossRef]

107. Bekheit, M.; Baddour, N.; Katri, K.; Taher, Y.; El Tobgy, K.; Mousa, E. Hyperbaric oxygen therapy stimulates colonic stem cells and induces mucosal healing in patients with refractory ulcerative colitis: A prospective case series. BMJ Open Gastroenterol. 2016, 3, e000082. [CrossRef]

108. Gardin, C.; Bosco, G.; Ferroni, L.; Quartesan, S.; Rizzato, A.; Tatullo, M.; Zavan, B. Hyperbaric Oxygen Therapy Improves the Osteogenic and Vasculogenic Properties of Mesenchymal Stem Cells in the Presence of Inflammation In Vitro. Int. J. Mol. Sci. 2020, 21, 1452. [CrossRef]

109. Lin, S.S.; Ueng, S.W.; Niu, C.C.; Yuan, L.J.; Yang, C.Y.; Chen, W.J.; Lee, M.S.; Chen, J.K. Effects of hyperbaric oxygen on the osteogenic differentiation of mesenchymal stem cells. BMC Musculoskelet. Disord. 2014, 15, 56. [CrossRef]

110. Chiu, C.H.; Chang, S.S.; Chang, G.J.; Chen, A.C.; Cheng, C.Y.; Chen, S.C.; Chan, Y.S. The Effect of Hyperbaric Oxygen Treatment on Myoblasts and Muscles After Contusion Injury. J. Orthop. Res. 2020, 38, 329-335. [CrossRef]

111. Chaillou, T.; Lanner, J.T. Regulation of myogenesis and skeletal muscle regeneration: Effects of oxygen levels on satellite cell activity. FASEB J. 2016, 30, 3929-3941. [CrossRef] [PubMed]

112. Horie, M.; Enomoto, M.; Shimoda, M.; Okawa, A.; Miyakawa, S.; Yagishita, K. Enhancement of satellite cell differentiation and functional recovery in injured skeletal muscle by hyperbaric oxygen treatment. J. Appl. Physiol. 2014, 116, 149-155. [CrossRef] [PubMed]

113. Zadori, A.; Agoston, V.A.; Demeter, K.; Hadinger, N.; Varady, L.; Kohidi, T.; Gobl, A.; Nagy, Z.; Madarasz, E. Survival and differentiation of neuroectodermal cells with stem cell properties at different oxygen levels. Exp. Neurol. 2011, 227, 136-148. [CrossRef] [PubMed]

114. Zhou, H.X.; Liu, Z.G.; Liu, X.J.; Chen, Q.X. Umbilical cord-derived mesenchymal stem cell transplantation combined with hyperbaric oxygen treatment for repair of traumatic brain injury. Neural Regen. Res. 2016, 11, 107-113. [CrossRef] [PubMed]

115. Geng, C.K.; Cao, H.H.; Ying, X.; Yu, H.L. Effect of mesenchymal stem cells transplantation combining with hyperbaric oxygen therapy on rehabilitation of rat spinal cord injury. Asian Pac. J. Trop. Med. 2015, 8, 468-473. [CrossRef]

116. Pan, H.C.; Chin, C.S.; Yang, D.Y.; Ho, S.P.; Chen, C.J.; Hwang, S.M.; Chang, M.H.; Cheng, F.C. Human amniotic fluid mesenchymal stem cells in combination with hyperbaric oxygen augment peripheral nerve regeneration. Neurochem. Res. 2009, 34, 1304-1316. [CrossRef] [PubMed]

117. Khan, M.; Meduru, S.; Pandian, R.P.; Rivera, B.K.; Kuppusamy, P. Effect of oxygenation on stem-cell therapy for myocardial infarction. Adv. Exp. Med. Biol. 2011, 701, 175-181.

118. Khan, M.; Meduru, S.; Mohan, I.K.; Kuppusamy, M.L.; Wisel, S.; Kulkarni, A.; Rivera, B.K.; Hamlin, R.L.; Kuppusamy, P. Hyperbaric oxygenation enhances transplanted cell graft and functional recovery in the infarct heart. J. Mol. Cell. Cardiol. 2009, 47, 275-287. [CrossRef]

119. Pena-Villalobos, I.; Casanova-Maldonado, I.; Lois, P.; Prieto, C.; Pizarro, C.; Lattus, J.; Osorio, G.; Palma, V. Hyperbaric Oxygen Increases Stem Cell Proliferation, Angiogenesis and Wound-Healing Ability of WJ-MSCs in Diabetic Mice. Front. Physiol. 2018, 9, 995. [CrossRef]

120. Torbati, D.; Church, D.F.; Keller, J.M.; Pryor, W.A. Free radical generation in the brain precedes hyperbaric oxygen-induced convulsions. Free Radic. Biol. Med. 1992, 13, 101-106. [CrossRef] 
121. Kellogg, R.H. “La Pression barometrique”: Paul Bert's hypoxia theory and its critics. Respir. Physiol. 1978, 34, 1-28. [CrossRef]

122. Leach, R.M.; Rees, P.J.; Wilmshurst, P. Hyperbaric oxygen therapy. BMJ 1998, 317, 1140-1143. [CrossRef] [PubMed]

123. Jain, K.K.; Torbati, D.; Tao, H.Y.; Ni, G.T. Oxygen Toxicity. In Textbook of Hyperbaric Medicine, 4th ed.; Best Publishing Company: North Palm Beach, FL, USA, 1999; pp. 47-59.

124. Hadanny, A.; Meir, O.; Bechor, Y.; Fishlev, G.; Bergan, J.; Efrati, S. The safety of hyperbaric oxygen treatment-retrospective analysis in 2334 patients. Undersea Hyperb. Med. 2016, 43, 113-122. [PubMed]

125. Hadanny, A.; Meir, O.; Bechor, Y.; Fishlev, G.; Bergan, J.; Efrati, S. Seizures during hyperbaric oxygen therapy: Retrospective analysis of 62,614 treatment sessions. Undersea Hyperb. Med. 2016, 43, 21-28. [PubMed]

126. Hadanny, A.; Zubari, T.; Tamir-Adler, L.; Bechor, Y.; Fishlev, G.; Lang, E.; Polak, N.; Bergan, J.; Friedman, M.; Efrati, S. Hyperbaric oxygen therapy effects on pulmonary functions: A prospective cohort study. BMC Pulm. Med. 2019, 19, 148. [CrossRef] [PubMed]

(C) 2020 by the authors. Licensee MDPI, Basel, Switzerland. This article is an open access article distributed under the terms and conditions of the Creative Commons Attribution (CC BY) license (http://creativecommons.org/licenses/by/4.0/). 